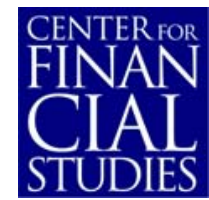

No. $2008 / 20$

Do the elderly reduce housing equity?

An international comparison

Maria Concetta Chiuri and Tullio Jappelli 


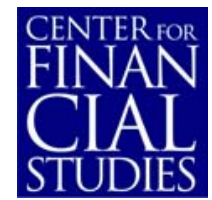

\section{Center for Financial Studies}

The Center for Financial Studies is a nonprofit research organization, supported by an association of more than 120 banks, insurance companies, industrial corporations and public institutions. Established in 1968 and closely affiliated with the University of Frankfurt, it provides a strong link between the financial community and academia.

The CFS Working Paper Series presents the result of scientific research on selected topics in the field of money, banking and finance. The authors were either participants in the Center's Research Fellow Program or members of one of the Center's Research Projects.

If you would like to know more about the Center for Financial Studies, please let us know of your interest.

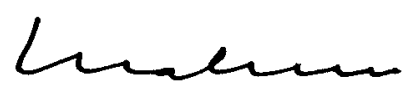

Prof. Dr. Jan Pieter Krahnen

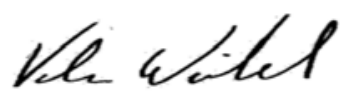

Prof. Volker Wieland, Ph.D. 


\title{
Do the elderly reduce housing equity? An international comparison*
}

\author{
Maria Concetta Chiuri ${ }^{1}$ and Tullio Jappelli ${ }^{2}$
}

\section{June 2008}

\begin{abstract}
:
We explore the pattern of elderly homeownership using microeconomic surveys of 15 OECD countries, merging 60 national household surveys on about 300,000 individuals. In all countries the survey is repeated over time, permitting construction of an international dataset of repeated cross-sectional data. We find that ownership rates decline considerably after age 60 in all countries. However, a large part of the decline depends on cohort effects. Adjusting for them, we find that ownership rates start falling after age 70 and reach a percentage point per year decline after age 75 . We find that differences across country ownership trajectories are correlated with indicators measuring the degree of market regulations.
\end{abstract}

JEL Classification: G2, R2

Keywords: Homeownership, Wealth Decumulation, Aging

\footnotetext{
* Acknowledgments: We thank for helpful comments the editor, two anonymous referees, Patrick Bolton, Andrea Brandolini, Janet Gornick, Elsa Roelle, Timothy Smeeding, Ernesto Villanueva, participants at the CSEF-IGIER Symposium on Economics and Institutions (Anacapri, 24-28 June 2007), the 2007 Aldi Hagenaars Memorial Lecture (Luxembourg, 29 June 2007), and the LWS Final Conference: Enhancing Comparative Research on Household Finance (Bank of Italy, 5-7 July 2007). This work has been supported in part by the European Union under contracts HPRN-CT-2002-00235 (Economics of Aging in Europe - AGE) and by the Italian Ministry of Universities and Research (MUR).

1 University of Bari, CSEF and CHILD.

2 University of Naples Federico II, CSEF and CEPR
} 


\section{Introduction}

Understanding the determinants of housing trajectories and asset allocation as people get older is receiving increasing attention. Often the elderly don't have enough resources to finance post-retirement consumption and medical expenses even though they own substantial assets in the form of housing equity. The recent increase in house prices has further tilted the assets of the elderly towards housing wealth, and particularly primary residence. From an economy-wide point of view, the rapid gains in life expectancy and the rising population share of the elderly will undermine the sustainability of national welfare systems unless the elderly will be able to finance an increasing portion of their expenditures by accumulated assets. To sustain post-retirement consumption people could switch from owning to renting or to owning a smaller unit. Alternatively, they can release housing equity by appropriate financial instruments (such as reverse mortgages or mortgage equity withdrawal) without selling their property.

Empirical studies, mostly based on US data, find limited evidence that the elderly decumulate housing wealth, see Feinstein and McFadden (1989) and Venti and Wise (2002; 2004). Rather, the evidence suggests that the elderly prefer to stay in their homes, unless they are forced to move by outside shocks - the death of a spouse, health problems, entry into a nursing home. The evidence for other countries is far more limited; what evidence there is broadly confirms the slow rates of housing decumulation by age observed in the US. One major issue that must be addressed in estimating the housing trajectories is that cross-sectional age are contaminated by cohort effects and that a significant component of the shape of the crosssectional profiles depends on cohort differences.

The literature is based on country data and, to our knowledge, a systematic international comparison of age-trajectories of homeownership is still lacking. In this paper we aim to see whether the absence of decumulation is confined to just a few countries, and if there are systematic patterns that can be related to international differences in financial markets, institutions or public policy. In earlier work, we found that the availability of mortgage finance as measured by loan-to-value ratios - affects the distribution of owner occupancy rates across age groups at the young end (Chiuri and Jappelli, 2003), and that in countries with less regulated 
mortgage markets (i.e. with higher loan-to-value ratios), the homeownership profile is more tilted towards the young. Here, we find that also cross-country differences in ownership trajectories among the elderly are highly correlated with the degree of mortgage market development and other indicators of economy-wide regulation. In particular, we find higher rates of wealth decumulation in countries where equity withdrawal is more difficult (such as Italy, France, Belgium and Germany) than in countries with more developed mortgage markets (US, UK, Denmark and Sweden).

The empirical analysis uses the Luxembourg Income Study (LIS), a collection of microeconomic data from several OECD countries. We select 60 national household surveys in 15 countries to study homeownership trajectories in old age. In each of these countries, we use repeated cross-sectional data, allowing us to compare cross-sectional and cohort-adjusted profiles. To control for selection issues and for the endogeneity of co-residence arrangements, we focus on individuals (not households) aged 50 to 80, a total of more than 300,000 observations.

The rest of the paper is organized as follows. Section 2 reviews the main empirical findings of the literature, mainly based on individual country data. Section 3 describes the microeconomic data and explains the importance of distinguishing between households and individuals. Section 4 presents the estimated age profiles. Section 5 relates changes in ownership rates across countries to the availability of equity withdrawal regulation and to economy-wide regulation. We find that countries with more regulated markets exhibit higher rates of housing decumulation. Section 6 summarizes our main findings.

\section{The evidence to date}

In developed countries wealth in real estate is the largest component of the assets of the elderly. The recent SHARE survey indicates that in Europe residential property accounts for 80 percent of wealth of households over $65 .{ }^{1}$ Primary residence is the largest component, as the fraction of homeowners in the eldest age brackets is 70 percent. Since residential wealth is 
illiquid and non-diversified, it may reduce the ability to smooth consumption through life and buffer unforeseen events, such as health shocks.

In principle, when negative income shocks occur and people need resources to finance consumption, homeowners could draw on home equity by financial services that do not require selling the house, such as refinancing the mortgage, or home equity lines of credit, such as reverse mortgages (Mitchell and Piggott, 2004). In particular, lower mortgage rates stimulate refinancing, allowing otherwise liquidity-constrained households to access their home equity and finance current consumption (Hurst and Stafford, 2004). Similarly, reverse mortgages would allow the elderly to borrow against the value of the house to increase consumption. ${ }^{2}$ However, such possibilities are available only in countries with well developed financial markets. Davidoff (2004) has pointed out that the elderly have a further way to convert home equity to consumption: lower home maintenance expenditures compared to other age groups. In such a way the elderly effectively can reduce equity without selling the home by letting the property deteriorate. $^{3}$

The age profile of homeownership is therefore a useful summary indicator of the asset allocation strategies of the elderly and has received considerable attention. It has also been cited as indirect evidence in favor or against life-cycle models. Even though the finding of low mobility rates among the elderly has been interpreted as a clash with the theory, it is not a necessary implication of life cycle models. First of all, housing wealth can be released even maintaining the house property. Secondly, observing a portfolio shift from real estate to other assets does not necessarily imply that households are running down their wealth.

Empirically, several papers provide evidence with US data showing that the elderly decumulate slowly housing equity, and do so only in limited cases. Feinstein and McFadden (1989), using the Panel Study of Income Dynamics (PSID), find a transition from owning to

\footnotetext{
${ }^{1}$ The Survey of Health, Assets, Retirement and Expectations (SHARE) has information on income, consumption, and assets of a sample of the population aged 50+ in 11 European countries.

${ }^{2}$ In this case no repayment is made until the homeowner dies, when the house is sold and the proceeds used to repay the loan.

${ }^{3}$ Data reported by Davidoff (2004) from the American Housing Survey data show that homeowners over 75 spend roughly .8 percent of home value less per year on routine maintenance than younger owners of similar homes.
} 
renting of less than one third of a percentage point per year. In a series of studies, Venti and Wise (2002; 2004) use a variety of microeconomic datasets (the Health and Retirement Study, the Asset and Health Dynamics Among the Oldest Old, and the Survey of Income and Program Participation) and find no decline in homeownership before age 75; and one averaging 1.76 percentage points per year thereafter. Substantial rates of decumulation (near 8 percentage points) are found only among households that undergo some precipitating shocks. They also find that decumulation rates do not vary by family composition or presence of children, which contradicts one basic argument of the bequest hypothesis, namely that families with children should decumulate wealth more slowly than singles.

Scattered international evidence confirms the US findings. Crossley and Ostrovsky (2003) construct a synthetic panel using 18 cross-sections from three Canadian microeconomic surveys and estimate cohort-adjusted profiles of homeownership. They find that the ownership rate declines by about 15 percentage points from the peak of 80 percent at age 50-55 to 65 percent at age 80. Their conclusion is "mildly supportive of the life-cycle model which suggests that we should observe at least some transition from ownership to renting in later life” (p. 15). Ermisch and Jenkins (1999), using five waves of the British Household Panel Survey, find that residential mobility of the elderly is rare in the UK as well. However, there is some evidence of residential downsizing, mainly due to retirement or to the loss of a spouse.

Although the literature is consistent in finding few evidence of residential mobility among the elderly, international comparisons might be able to spotlight the forces that curb it. The first paper to take this perspective is Börsch-Supan (1994), who compares housing choices made by the elderly in the US and West Germany. Using the PSID and the German Socio-Economic Panel, Börsch-Supan finds that ownership rates peak in the 55-59 age-group in both countries, at different levels, and decline thereafter at a similar pace. Börsch-Supan suggests that part of the difference in the level of homeownership may reflect the homeownership subsidy policy in the US and the rent adjustment provision in Germany.

Tatsiramos (2006) is the only systematic attempt to compare homeownership profiles in different EU countries, using data for six countries in the European Community Household Panel from 1994 to 2001. He finds residential mobility among the elderly of 1.5 percent per year in Southern Europe (Italy and Spain) and 3 percent in Central Europe (France, Germany, the 
Netherlands) and the UK; in Central Europe downsizing tends to be associated with retirement, in Italy and Spain more often with dramatic events such as the death of the spouse.

In this paper, we consider a long time span of a much larger set of countries to investigate whether the absence of housing decumulation may be typical of just a few countries, and whether there are patterns relating to international differences in financial market development, national institutions or public policy, on top of genuine preferences for owning over renting.

\section{The international dataset}

Wealth data are generally hard to come by or to compare internationally. In this respect, the Luxembourg Income Study (LIS) is a unique data-set, based on a research project by CEPSINSTEAD to enhance international comparability among several household surveys. We take fifteen OECD countries (Australia, Austria, Belgium, Canada, Denmark, Finland, France, Germany, Ireland, Italy, Luxembourg, Netherlands, Sweden, United Kingdom and United States); other potentially interesting countries are excluded for lack of data on home ownership. Each of the 60 surveys selected has information on the demographic characteristics of the household and home ownership.

The sample period spans three decades overall. In all countries the cross-section is repeated over time, providing an opportunity to exploit time-variability in the owner occupation rates of various age groups within and across countries. The earliest surveys are for the United States (the 1974 March Current Population Survey) and Canada (the 1975 Survey of Consumer Finances), the most recent for Belgium (the 2000 Panel Study of Belgian Households), Canada (the 2000 Survey of Labour and Income Dynamics), Finland (the 2000 Income Distribution Survey), Germany (the 2000 German Socio Economic Panel Study), Italy (the 2000 Survey of Household Income and Wealth), Luxembourg (the 2000 Luxembourg Socio Economic Panel Study), and the US (the 2000 March Current Population Survey). In some cases the survey design has changed (as in Germany, before and after re-unification). For Belgium, Canada, Ireland, the Netherlands and the UK we rely on two different surveys. Table 1 provides further details.

In most of the empirical studies based on microeconomic surveys, the unit of analysis is the 
household. However, in our framework the standard procedure might induce selection bias, as the dissolution of households due, say, to the death of a spouse, might interact with homeownership status. Many elderly people deal with this precipitating shock by moving in with their children. Standard empirical analysis would refer to the sample of households in the selected group of people who remain independent, and are still therefore homeowners. But those who move in with their children are effectively "renters" who disappear from the sample of household heads.

Following this argument, we think it is important to check if there is a discrepancy between the two distributions of household heads and individuals by age. Accordingly we define ownership on an individual rather than on a household basis, and take a sample of all women aged 50 to 80, regardless of whether they are living alone, with their husband, with their children or with other persons. ${ }^{4}$

We exclude women older than 80 (regardless of year of birth) for two main reasons. First, the choice is motivated by the potential sample bias arising by mortality: it is well known that survival probabilities are correlated with wealth and owner occupancy rates, which implies that the non-survivors will have lower wealth and ownership rates than the survivors. A second source of potential bias is related with the entrance in a nursing home. Elderly selling their house and buying long-term care are not represented in national household surveys. This bias might be particularly important for the eldest old. For both reasons, our survey data on the very old $(80+)$ should not be regarded as representative.

Table 2 reports the proportion of household heads and women in three age brackets (51-60, 61-70 and 71-80). By taking women as the unit of analysis we increase the incidence of older people in our sample by about 2 percentage points, because - on average - 2 percent of elderly women are merged with other households and don't appear as independent units. Since the size of the potential bias is not large, we obtain similar results performing the analysis at the individual or household level. We choose to present results for women, and regard the robustness of the analysis when homeowners are defined in terms of households as a point in favor of our analysis.

The distribution of women by owner-occupancy rate is reported in Table 3 aggregated in

\footnotetext{
${ }^{4}$ We choose to perform the analysis for women instead of men, because women have longer life expectancies, and are more likely to survive men than the other way around.
} 
three age bands. In all countries we observe large decline in homeownership by age. There are also substantial country differences. While Denmark and Finland display rapid declines in owner occupancy rates, in Australia, Ireland and the US about 70 percent of the sample still own their house at age 75. It should be noted, however, that Table 3 is based on cross-sectional profiles; as we shall see in Section 4, cohort-adjusted profiles deliver a different picture.

\section{Estimating ownership trajectories}

Use of cross-sectional data to estimate ownership profiles can be highly misleading (Shorrocks, 1975; Mirer, 1979). The individuals interviewed in any cross-section belong to generations that differ in mortality rates, preferences, institutional arrangements, and resources. For instance, a finding that ownership declines with age in a cross-section may be due to the fact that older generations are less productive, or have different preferences of owning relative to renting. ${ }^{5}$ In short, in a cross-section one cannot identify both age and cohort effects: in year $t$, the difference in housing wealth between a 50 year old and a 51 year old is equivalent to the wealth difference between someone born in year $t$-50 and someone born in $t$-51.

There are two ways to control for the presence of cohort effects: panel data and repeated cross-sectional data. Wealth panel data allow the econometrician to track wealth trajectories of one particular cohort of retirees. For instance, Diamond and Hausman (1984), find rates of dissaving after retirement of about 5 percent per year in the National Longitudinal Survey of Mature Men. Hurd (1987), using the Retirement History Survey, finds decumulation rates of about 1.5 percent per year, emphasizing that couples with independent children dissave more during retirement than childless couples. The second approach, pioneered by Shorrocks (1975) and Masson (1986), is to control for differences in productivity and preferences between generations using a time-series of cross-sectional data. ${ }^{6}$ Repeated cross-sections allow the

\footnotetext{
${ }^{5}$ In the literature, this preference is usually explained by the fact that owning eliminates the principalagent relationship, i.e. the owner can make alterations as desired and is not subject to eviction or rent increases.

${ }^{6}$ Shorrocks (1975) used 60 years of estate-duty statistics, concluding that wealth is an increasing function of age. These statistics over-represent the most affluent households. Masson (1986) constructed cohort-
} 
econometrician to track cohorts over time. Although the same individual is only observed once, a sample from the same cohort is observed in a later survey.

Following the repeated cross-sectional approach, we aggregate the data by taking averages of the home ownership rates and the control variables for each age/year/country. In our 15 countries we define 30 age groups (from age 51 to 80 ) in each of 60 surveys, spanning the period 1974-2000.

Our econometric model posits that in each country the proportion of home owners $H$ of age $a$ born in year $b$ is a function of age, a set of demographic variables $X$ (such as working status and education) that vary with age or cohort, year of birth $b$ and an error component $(\varepsilon)$ :

$$
H_{a, b}=\alpha+f(a)+\beta X_{a, b}+\delta b+\varepsilon_{a, b}
$$

Age, time and cohort effects cannot all be separately identified. Therefore we express homeownership as a combination of age and year-of-birth, dropping time dummies and interaction terms between age, time and cohort. Since the age effect is likely to be non-linear, we choose a third order polynomial in age. Results using a quadratic age polynomial, or a quadratic cohort polynomial are similar.

As a proxy for household resources and preferences, in some specifications we control for work status and education. We recode the education variable contained in the original surveys into three levels (low, middle and high), based on the 7 categories defined by the International Standard Classification of Education (ISCED, 1997). We expect the decline in ownership of couples to be lower than that of singles, as couples have greater life expectancy. Previous evidence shows that retirement is associated with a transition from owning to renting. Therefore we expect those who are working to exhibit higher ownership rates.

The assumption that age profiles and cohort effects are the same in all countries is restrictive. Indeed, an F-test between a restricted specification assuming the same cohort and age profiles and an unrestricted regression with full interaction of all variables with country dummies overwhelmingly rejects the null hypothesis that the slope coefficients are the same across 
countries. We therefore proceed with the analysis estimating separate regressions and ownership profiles for each country.

Regressions are estimated with grouped data, each cell consisting of an age/year of birth observation $^{7}$. Since the cells represent different numbers of observations, in each country we use a weighted least squares method, taking as weights $w_{a, b, c}=\left[\frac{n_{a, b}}{h_{a, b}\left(1-h_{a, b}\right)}\right]^{\frac{1}{2}}$, where $n$ and $h$ are, respectively, the number of observations and the probability of ownership in age group $a$ and year of birth $b$. Since the sample in each country is a collection of different surveys, we must consider that observations within each survey could be correlated. The correlation might inflate the standard errors, an application of neighborhood effects induced by survey designs that are based on clusters of observations (Deaton, 1997, p. 73-78). We therefore use a robust variancecovariance matrix assuming that observations in different samples are independent, but not necessarily those within each individual survey. ${ }^{8}$

As mentioned, we estimate cross-sectional and cohort-adjusted ownership trajectories separately for each country. Rather then reporting the regression results, we show the results graphically in Figure 1, comparing the cross-sectional and cohort-adjusted profiles. In each of the country regression, the hypothesis that the age coefficients are jointly equal to zero is rejected at the 1 percent level. As one expects if homeownership increases, on average, over time, in all countries the cross-sectional profile lies below the cohort-adjusted profile, showing that homeownership is higher for younger cohorts.

decumulation ranging from 0.7 percent for wealthy self-employed persons to 3-4 percent for wage earners. ${ }^{7}$ We also checked if cells could have been defined on the basis of education. The fraction of individuals with "college degree" in the elderly population is quite small in several countries, so this procedure ends up selecting very small cells in several countries, preventing reliable estimates of the fraction of homeowners. For instance in Austria in 1997 the average cell size of women in the age group 75-80 with college degree is only 4, and in Luxembourg in 1985 there were no individuals aged 75-80 with college degree.

${ }^{8}$ Detailed information on clustering and stratification in individual surveys is not available. We therefore proceed under the assumption that in each country the surveys are drawn randomly, and that individual errors are uncorrelated between different surveys. This assumption is questionable, because some of the underlying surveys in the LIS are panel datasets or contain a panel section (e.g., the Italian SHIW). However, since we run individual country regressions, the residual correlation between sampling units should not be an excessively great concern. 
Figure 2 provides further details on the estimated cohort effects plotting, by country, the estimated coefficients of year-of-birth in the individual country regressions. Each of the estimated coefficients is statistically different from zero at least at the 5 percent level. The figure shows that the cohort effect is largest (about one percentage point) in Austria, Italy, Luxembourg and the UK. At the other extreme, Australia, Canada and the US exhibit the lowest cohort effects (about 0.1 points per year of birth).

To gain further insights into the ownership trajectories, in Figures 3, 4 and 5 we plot the change in the cohort-adjusted homeownership rates implied by our regression estimates between age 65 and 70, age 70 and 75, and age 75 and 80. Except Belgium in the 65 to 70 change (Figure 3), all countries exhibit negative changes. However, there is great variability, both across age groups as well as between countries.

In the age-group 65-70 decumulation rates are generally small (less then 2 percentage points over a 5-year interval). In the age-groups 70-75 and 75-80 decumulation rates are more substantial (3.1 and 4.2 points, respectively). But the most interesting finding is that there is considerable dispersion across countries, particularly from age 75 to 80: in Belgium, Finland, France and Italy the ownership rate falls by 6 to 8 percentage points, whereas in Denmark, Ireland, Luxembourg and the UK the change in the cohort-adjusted profile is less than 2 points. Finally, Australia, Austria, Canada, Germany, Sweden, and the US display intermediate values.

We check the robustness of the estimated cohort-adjusted profiles adding demographic variables to the country regressions. High school or college degree is generally associated with higher homeownership probability. Being married and being employed are also generally associated with higher ownership rates. Controlling for these additional variables, we find decumulation rates of the cohort adjusted profiles very similar to those displayed in Figures 2, 3 and 4 . For brevity these profiles are not reported and are available upon request.

\section{International differences in ownership trajectories}

In this section, using the estimated cohort-adjusted age profiles of ownership, we try to explain international differences in ownership trajectories. Among the many possible factors 
affecting the rate at which ownership changes across countries, we focus on transaction and moving costs, the availability of mortgage equity withdrawal, property taxes, generosity of the social security systems, unanticipated health expenditure, availability of nursing homes for the elderly and differences in mortality rates.

Previous literature suggests that well-functioning rental markets increase the likelihood that the elderly will downsize or sell their house, and that moving costs from owning to renting explain in part the low propensity to move by the elderly. Indeed, mobility rates from owning to renting tend to be negatively correlated with transaction costs (e.g. the costs of house buying and selling), and the degree of the economy's regulation.

Different regulations affect also the development of mortgage markets, the availability of housing and the age at which individuals buy their homes. This is particularly relevant for young households. Ortalo-Magné and Rady (1999; 2006) show that in the absence of a bequest motive, a higher down-payment ratio reduces the equilibrium distribution of homeownership rates of young generations. Chiuri and Jappelli (2003) provide econometric evidence showing that the loan-to-value ratio is an important determinant of the timing of home purchase and of the ownership rates of the young. In countries with tighter credit markets (e.g., with lower loan-tovalue ratios) they find lower levels of ownerships among the young than in countries where credit is more easily available.

The degree of financial market development might also explain the availability of financial instruments that the elderly can use to reduce their stock of housing wealth. In this context, reverse mortgages are potentially important, allowing house-rich but cash-poor old people to sustain consumption without leaving their property. ${ }^{9}$ Even though at present transaction costs and up-front fees tend to reduce take-up rates among the elderly, financial experts expect these products to become appealing in the future (Mitchell and Piggott, 2004 and Mitchell, Piggott, Sherris and Yow, 2006). ${ }^{10}$ There is also some evidence that reverse mortgages tend to reduce ownership transitions. In an empirical study using data from the US Home Equity Conversion

\footnotetext{
${ }^{9}$ Reverse mortgage allow homeowners to make use of any equity they have in their property. Under the most common type of scheme, the mortgage-backed equity release scheme, a lender gives the homeowner either a lump sum or instalments (or both) on the basis of the value of their home. Lenders will receive their returns when the loan matures, typically on the death or disablement of the borrower.
} 
Mortgage (HECM) program, Davidoff and Welke (2007) find that reverse mortgages have enabled people to stay at home longer, although the kind of people who want to get cash out of their housing wealth turn relatively soon thereafter to disposal of the entire asset.

Wherever reverse mortgages are available (Australia, Canada, the US and the UK) as well as in Denmark, Finland, Ireland, the Netherlands, and Sweden people can also withdraw housing equity increasing their debt by more than investment in the housing stock. In particular, there are several methods of withdrawing housing equity without the need to sell the property. The ways that are mostly relevant in the present study are over-mortgaging, re-mortgaging, trading down, or second mortgage. ${ }^{11}$ The hypothesis that we wish to test is if ownership trajectories are flatter in countries with relatively more developed access to housing equity withdrawal.

In many countries the tax code gives preferential treatment to owning as against renting. One of the most compelling reasons for these incentives is to shift the allocation of wealth towards goods to which society assigns an important weight in creating positive externalities and improving living conditions, much as targeting retirement saving is a remedy to household myopia and free-riding. In some countries (e.g. the US), property taxes are potentially important determinants of the decision to reduce home equity, as they are the main way to finance local public services, such as schools or transports. In general, high legal costs and transaction taxes might be expected to induce the elderly to prefer downsizing by simultaneously renting a smaller unit and letting their house.

A further factor that needs to be explored is that the generosity of the social security system might also be related to the portfolio strategies of the elderly: in countries with more generous pensions there is less need to finance post-retirement consumption selling the primary residence. On the other hand, the increased generosity of the social security system in several OECD countries might be associated to higher rates of homeownership among the elderly. Engelhardt (2008) using data from 1978 to 2001 Current Population Surveys finds evidence of a causal

${ }^{10}$ In the US, reverse mortgages were authorized in 1987. In Canada borrowers receive a small public subsidy. In the UK local governments have been recently involved in granting the loans.

${ }^{11}$ Trading down occurs when a seller moves to a cheaper property, but reduces the mortgage by less; overmortgaging if moving to a more expensive home, an owner-occupier increases the mortgage by more than the price between the old and the new house. Finally, re-mortgaging or second mortgage happens when a homeowner increases an existing mortgage or takes a second mortgage, but does not use the funds to improve the property or buy another one. 
relation between the value of Social Security benefits and the homeownership rate of households 65 years or older, which has risen steadily in the US in the last twenty years. ${ }^{12}$

Cross-country differences in the decumulation rates among the elderly might be related to differences in the choice of entering in a nursing home. In this respect the local availability of long-term care services could raise the incentive to sell the house. Since in some countries home equity could play the role of a buffer stock against unanticipated risks, such as medical expenses, we will also consider the potential role of public health care expenditures. Finally, although the differences in mortality rates across the selected OECD countries included in our analysis is relatively small, still illness and death occur with different frequency across countries. We therefore explore the contribution of life expectancy rates of specific elderly cohorts to differences in homeownership.

To explain international patterns of ownership trajectories, we collected a wide range of variables and indicators potentially related to the incentive to reduce home equity. Some of these variables are reported in Table 4: an index of mortgage market regulation (taken from Tsatsaronis and Zhu, 2004), as a proxy for limited mortgage market development, an index of economy-wide regulation (Nicoletti and Scarpetta, 2003) covering many different regulatory areas, property taxes as percentages of national GDP (drawn from OECD, 2002) and average number of beds in nursing homes per thousand inhabitants (taken from OECD, 2005).

Figure 6 shows that cohort-adjusted changes in ownership rates between age 75 and 80 correlates negatively with the selected index of mortgage market regulation. On the basis of such evidence, in countries such as Austria, Belgium, Germany, Italy and France that feature less developed and efficient mortgage markets the elderly are more likely to decumulate housing wealth. The UK, Canada, Ireland, Denmark and the US are on the other side of the spectrum, with relatively low rates of wealth decumulation and more developed mortgage markets.

Regulation in financial market is highly correlated with other economy-wide regulations. This is confirmed by the strong correlation between our index of mortgage market regulation and

\footnotetext{
${ }^{12}$ Using data from the March 1978 to 2001 Current Population Surveys, Engelhardt (2008) develops an instrumental-variable approach that relies on the large variation in Social Security benefits for birth cohorts from 1900 to 1930 due to double indexation of the system and the so-called Social Security "notch." Overall, the estimates indicate that between half and as much as all of the time-series rise in
} 
the index of economy wide regulation. Moreover, in Figure 7 we find evidence supporting this view, as changes in homeownership are also negatively correlated with the index of economywide regulation.

To summarize the empirical correlations, we then regress the change in homeownership on the set of indicators selected. Table 5 reports regressions for cohort-adjusted changes in ownership from age 70 to 75 , and from age 75 to 80 . When we consider the cohort-adjusted changes in ownership from age 70 to 75 (the first three regressions) we find that the coefficients of the index of mortgage and economy-wide regulation are negative but not statistically different from zero at the 10 percent level.

The evidence is stronger when we consider the change from age 75 to 80: the coefficients of the index of mortgage market regulation (in column 4), or alternatively, the index of economywide regulation (in column 5) are negative and statistically different from zero and larger in size compared to the previous age group. In order to distinguish between the separate impact of the two indicators, we run a regression including both. The coefficients are both negative, but not precisely estimated (only the coefficient of economy-wide regulation is statistically different from zero at the 10 percent level), due to the high correlation coefficient between the two variables (0.82). Similar results are also found when cohort-adjusted changes in ownership are obtained from age profiles estimates that control for education and working status. The coefficients of both indicators are negative and statistically different from zero, but imprecisely estimated when both are used at the same time (as in the last regression of Table 5).

Both indicators (mortgage market regulation and economic regulation) might be driven by an omitted variable, related to historical differences in "liberalism". As stressed by Glaeser and Schleifer (2002), recent research identifies systematic differences between French Civil Law and Common Law countries in a variety of social outcomes. Holding the level of economic development constant, French Civil Law countries have less secure property rights, greater government regulation and intervention, greater government ownership of banks and industry, and higher levels of corruption and red tape than do Common Law countries (p. 1220). We therefore add a dummy for English origin, taken from La Porta et al (1998). The dummy is not

elderly homeownership over the last twenty-five years can be attributable to the rise in Social Security benefits. 
statistically different from zero. ${ }^{13}$

Finally, in all specifications we find no direct evidence that either "property taxes to GDP ratio" or "number of beds in nursing homes per thousand inhabitants" are related to the change in ownership rates among the eldest group. ${ }^{14}$

Even though the sample size is admittedly limited, our empirical findings don't contradict the view that market regulation and financial market development - as proxied by the availability of mortgage equity withdrawal and mortgage market regulation - affect the distribution of owner occupancy rates across age groups among the eldest old.

Our international-based evidence should be taken only as suggestive of empirical correlations that might be present in the data. Ideally, experimental designs are preferable to test for the effects of regulations and institutions on exit rates from homeownership. The work of Engelhardt and Cunningham (2008) on the effect of the 1997 Taxpayer Relief Act in the US provides one example in this direction. ${ }^{15}$ It is hoped that more of such studies and experimental designs will be available also to other OECD countries.

\footnotetext{
${ }^{13}$ To understand if the results are not driven by differences in some form of cultural liberalism we also used two further indicators taken from the World Value Survey (2000). "Government responsibility” takes value 1 if respondents think that the government should take more responsibility to ensure that everyone is provided for, and 10 if they think that people should take more responsibility to provide for themselves. "Competition good or harmful" takes the value 1 if respondents think that competition is good (it stimulates people to work hard and develop new ideas), and 10 if they think that competition is harmful (it brings out the worst in people). Both variables are computed for individuals in the age classes $70-75$ and 75-80. The coefficients of both regressors were not statistically different from zero.

${ }^{14}$ Other potentially relevant indicators were also considered, such as taxes on imputed rent, as a measure of property tax incidence, the social security income replacement rate, as a proxy for the importance of social security wealth in total wealth around retirement and price-to income ratio to capture the potential role plaid by housing prices. We also took into account the share of population covered by public health care and the public health expenditure as percentage of the total health expenditure. In order to control for differences in mortality rates we included life expectancy. However, we did not find any significant correlation between these variables and change in ownership.

${ }^{15}$ Cunningham and Engelhardt (2008), utilizing data drawn from the Current Population Survey (CPS) and a difference-in-difference approach, suggest that the repeal of the differential capital-gains tax embodied in the 1997 Taxpayer Relief Act raised the mobility rate by around 1-1.4 percentage points of homeowners in their early 50s.
} 


\section{Conclusion}

The paper estimates age-profiles of homeownership for the elderly using microeconomic surveys of 15 OECD countries. For each of them, the surveys are repeated over time. This gives an international dataset of repeated cross-sectional data, merging information from 60 national household surveys. The analysis is conducted at the level of individuals, not households, and therefore is not subject to the critique of the endogeneity of household formation and dissolution. We find that ownership rates decline considerably after age 60 in most countries, but that much of the decline is due to cohort effects. After adjusting for these effects, we find that ownership generally declines after age 70 in virtually all countries, reaching a rate of about 1 percentage point per year after age 75. Although the decline is slow, as previous literature has found for single countries, and our sample limited, the international comparison suggests that indicators of market regulation are correlated with ownership trajectories and therefore with the wealth allocation of the elderly. 


\section{References}

Almeida, H., M. Campello, and C. H. Liu (2006), “The Financial Accelerator: Evidence From International Housing Markets.” Review of Finance 10, 321-52.

Börsch-Supan, A. (1994), “Aging In Germany and the United States: International Comparisons.” In Studies in the Economics of Aging, D.A. Wise ed. Chicago: University of Chicago Press.

Chiuri, M. C., and T. Jappelli (2003), "Financial Market Imperfections and Home Ownership: a Comparative Study.” European Economic Review 47, 857-875.

Crossley T., and Y. Ostrovsky (2003), “A Synthetic Cohort Analysis of Canadian Housing Careers.” Social and Economic Dimensions of an Aging Population Research Papers, n. 107, Mc Master University, Canada.

Cunningham, C. R and G. V. Engelhardt, (2008) "Housing capital-gains taxation and homeowner mobility: Evidence from the Taxpayer Relief Act of 1997.” Journal of Urban Economics, forthcoming.

Davidoff, T. (2004), “Maintenance and the Home Equity of the Elderly.” Fisher Center for Real Estate and Urban Economics Paper No. 03-288.

Davidoff, T., and G. Welke (2007), "Selection and Moral Hazard in the Reverse Mortgage Market.” Mimeo, UC Berkeley.

Deaton, A. (1997), The Analysis of Household Surveys: A Microeconometric Approach to Development Policy. Baltimore: The John Hopkins University Press.

Diamond P.A., and J. A. Hausman (1984), "Individual Retirement and Saving Behavior." Journal of Public Economics 23, 81-114.

Engelhardt, G. V. (2008), "Social Security and Elderly Homeownership.” Journal of Urban Economics 63, 280-305.

Ermisch, J.F., and S.P. Jenkins (1999), "Retirement and Housing Adjustment in Later Life: Evidence from the British Household Panel Survey.” Labour Economics 6, 311-333.

Feinstein, J., and D. McFadden (1989), "The Dynamics of Housing Demand by the Elderly: Wealth, Cash Flow and Demographic Effects." In The Economics of Aging, D.A. Wise ed. Chicago: University of Chicago Press.

Glaeser, E., and A. Shleifer (2002), “Legal Origins.“ Quarterly Journal of Economics 118, 11931230.

Hurd, M. D. (1987), “Savings of the Elderly and Desired Bequests.” American Economic Review 77, 298-312.

Hurd, M. (1990), "Research on the Elderly: Economic Status, Retirement, and Consumption and Saving.” Journal of Economic Literature 28, 565-637. 
Hurst, E., and F. Stafford (2004), "Home is Where the Equity is: Mortgage Refinancing and Household Consumption.” The Journal of Money, Credit and Banking 36, 985-1014.

La Porta, R., F. Lopez-de-Silanes, and A. Shleifer (1998), “Law and Finance.” Journal of Political Economy 106, 1113-55.

Masson, A. (1986), “A Cohort Analysis of Wealth-Age Profiles Generated by a Simulation Model in France (1949-75).” Economic Journal 96, 173-90.

Mirer, T.W. (1975), “The Wealth-Age Relation among the Aged.” American Economic Review 69, 435-43.

Mitchell, O.S., and J. Piggott (2004), “Unlocking Housing Equity in Japan.” Journal of the Japanese and International Economies 18, 466-505.

Mitchell, O.S., J. Piggott, M. Sherris and S. Yow (2006), "Financial Innovation for an Aging World.” In Demography and Financial Markets, C. Kent, A Park, D Rees eds. Pegasus Press, 299-336.

Nicoletti, G., and S. Scarpetta (2003), "Regulation, Productivity and Growth: OECD Evidence," Economic Policy 18, 9-72.

OECD (2002) Revenue Statistics 1965-2001. OECD, Paris.

Ortalo-Magné, F., and S. Rady (1999), "Boom in, Bust out: Young Households and the Housing Price Cycle.” European Economic Review 43, 755-766.

Ortalo-Magné, F., and S. Rady (2006), "Housing Market Dynamics: On the Contribution of Income Shocks and Credit Constraints.” Review of Economic Studies 73, 459-85.

Shorrocks, A. F. (1975), “The Age-Wealth Relationship: A Cross-Section and Cohort Analysis.” Review of Economics and Statistics 57, 155-63.

Tatsiramos, K. (2006), "Residential Mobility and the Housing Adjustment of Older European Households in Europe.” IZA Working Paper n. 2435.

Tsatsaronis, K., and H. Zhu (2004), “What Drives Housing Price Dynamics: Cross-Country Evidence.” BIS Quarterly Review 65-78 (March).

UNESCO, (1997) International Standard Classification of Education. Paris: UNESCO.

Venti, S.F., and D.A. Wise (2002), “Aging and Housing Equity.” In Innovations in Retirement Financing, Z. Bodie, P. Hammond and O. Mitchell eds. Philadelphia: University of Pennsylvania Press.

Venti, S.F., and D.A. Wise (2004), “Aging and Housing Equity: Another Look.” In Perspective in the Economics of Aging. Chicago: University of Chicago Press. 
Figure 1

The cross-sectional and cohort-adjusted profiles of ownership

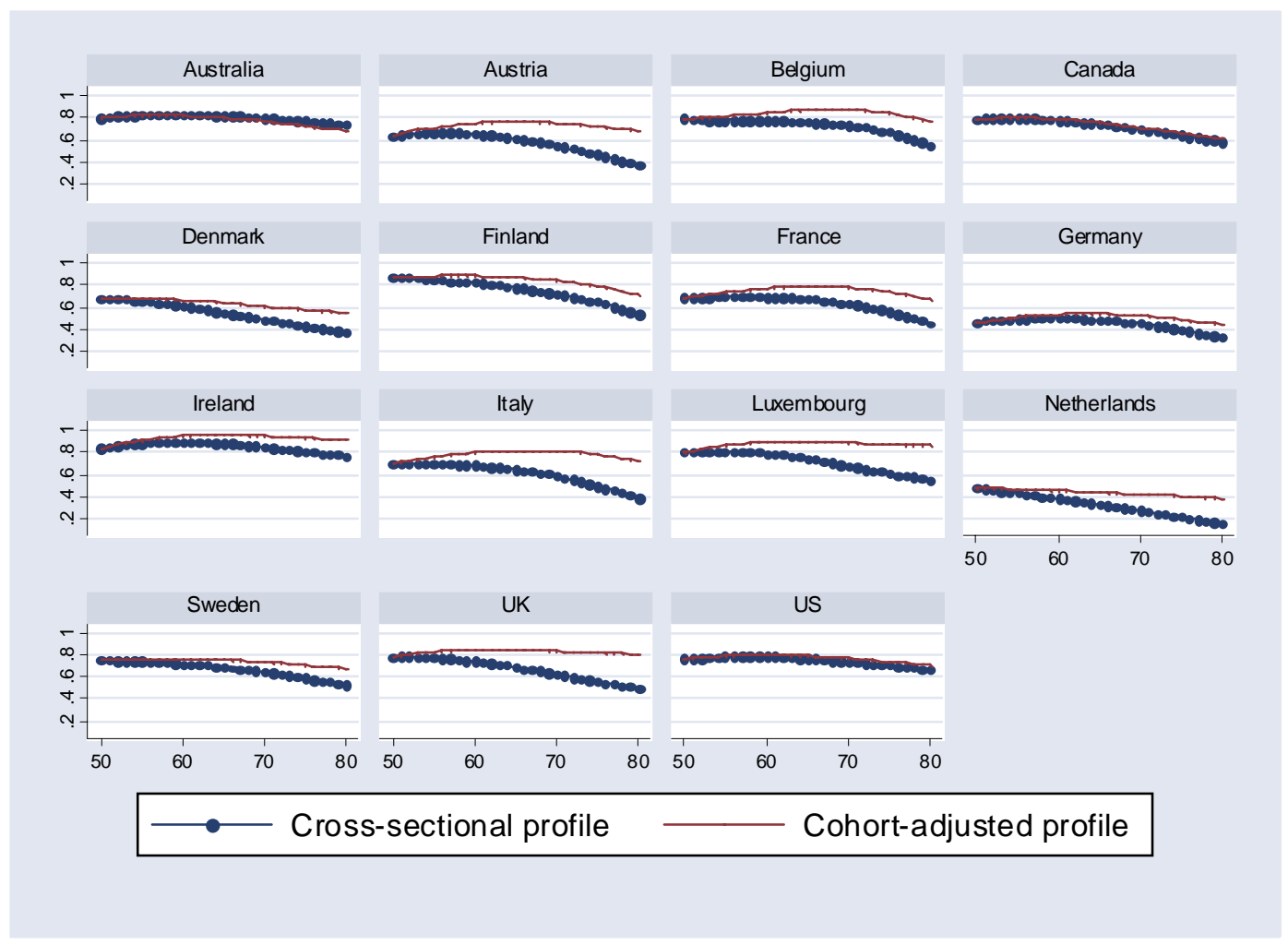

Note. The country-specific cross-sectional profiles are obtained by the age effect generated by a regression of homeownership on a third-order age polynomial. The cohort-adjusted profiles are obtained by the age effect generated by a regression of homeownership on a third-order age polynomial and "year-of-birth". In each country, data refer to women aged 50 to 80. 
Figure 2

The estimated cohort effects in ownership

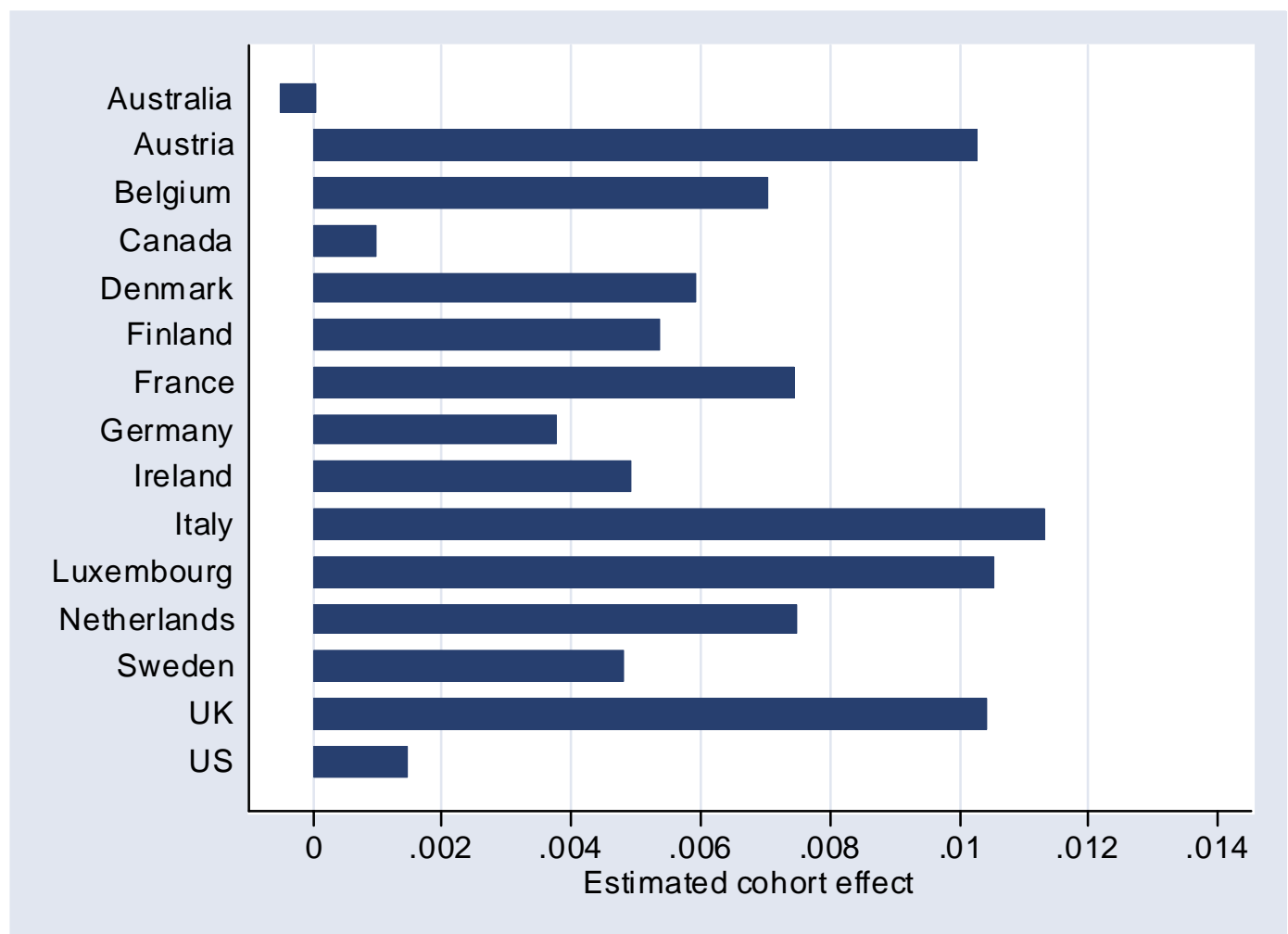

Note. The country-specific cohort effects are the coefficients of year-of-birth in a regression of homeownership that includes also a third-order age polynomial. In each country, data refer to women aged 50 to 80 . 
Figure 3

Change in ownership: age 65 to 70

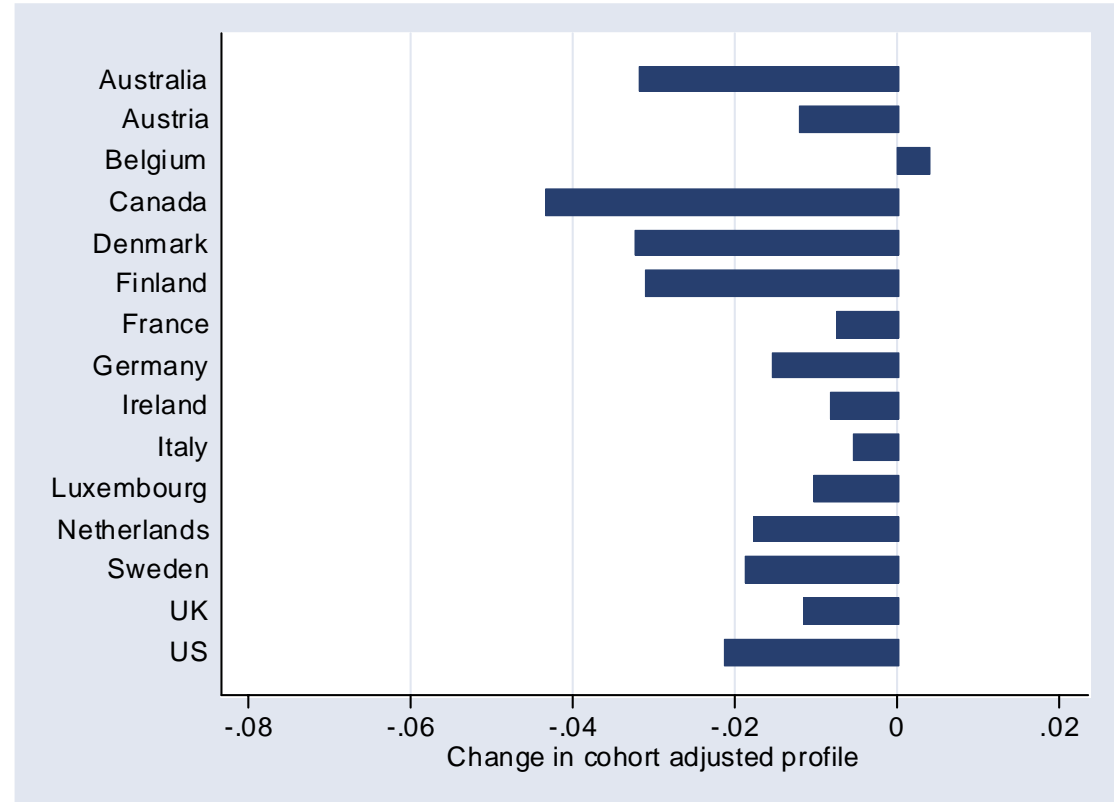

Note. The difference in ownership rate from age 65 to 70 is calculated from the country-specific cohortadjusted profiles displayed in Figure 2.

Figure 4

Change in ownership: from age 70 to 75

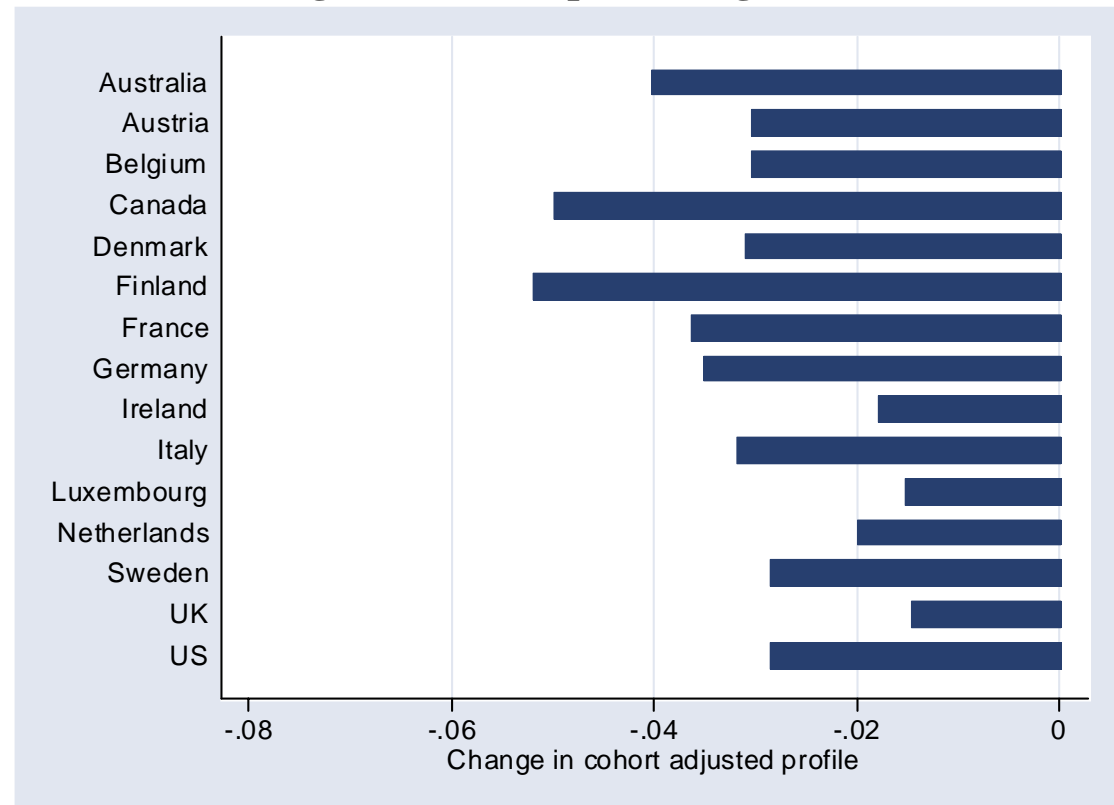

Note. The difference in ownership rate from age 70 to 75 is calculated from the country-specific cohortadjusted profiles displayed in Figure 2. 
Figure 5

\section{Change in ownership: from age 75 to 80}

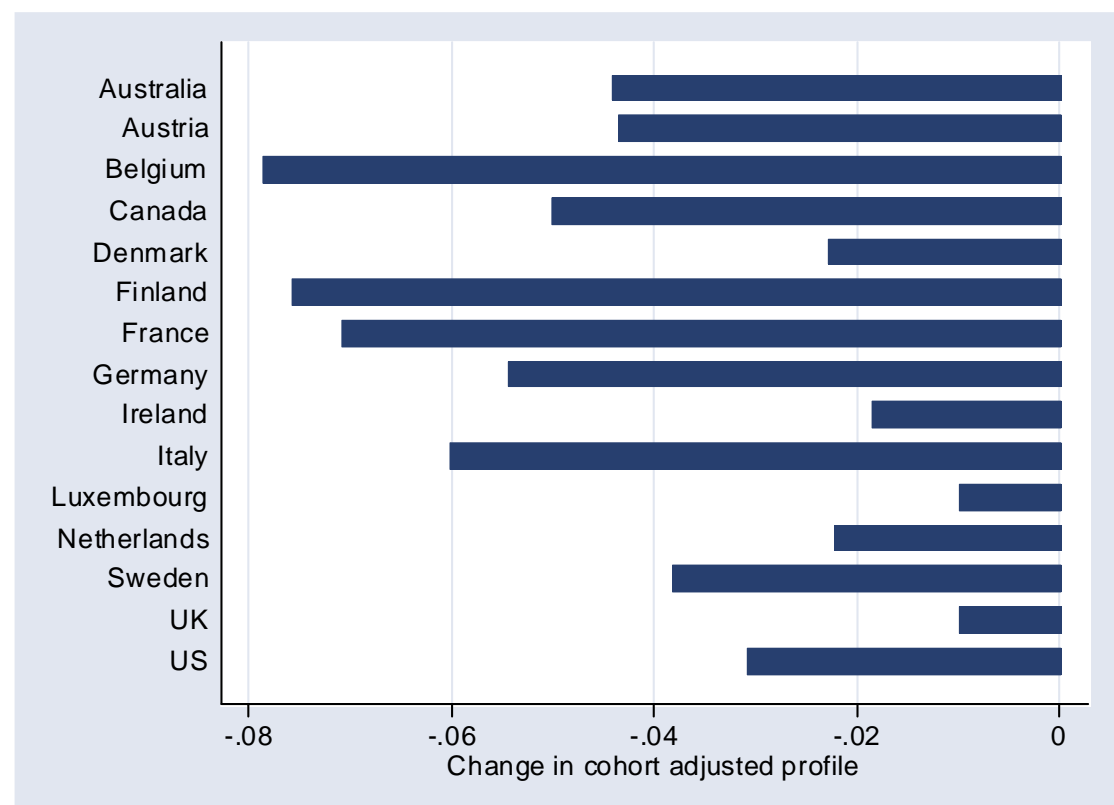

Note. The difference in ownership rate from age 75 to 80 is calculated from the country-specific cohortadjusted profiles displayed in Figure 2. 
Figure 6

Change in ownership from age 75 to 80 and mortgage market regulation

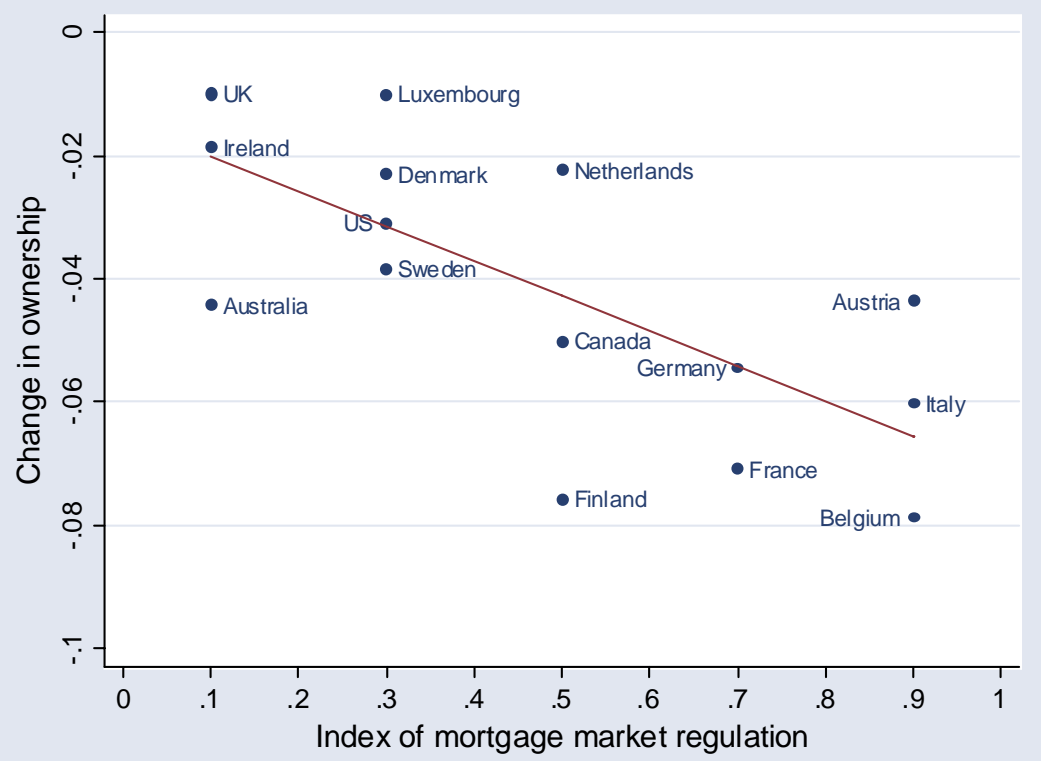

Note. The change in ownership is the cohort-adjusted change in ownership between age 75 and 80 .

Figure 7

Change in ownership from age 75 to 80 and economy-wide regulation

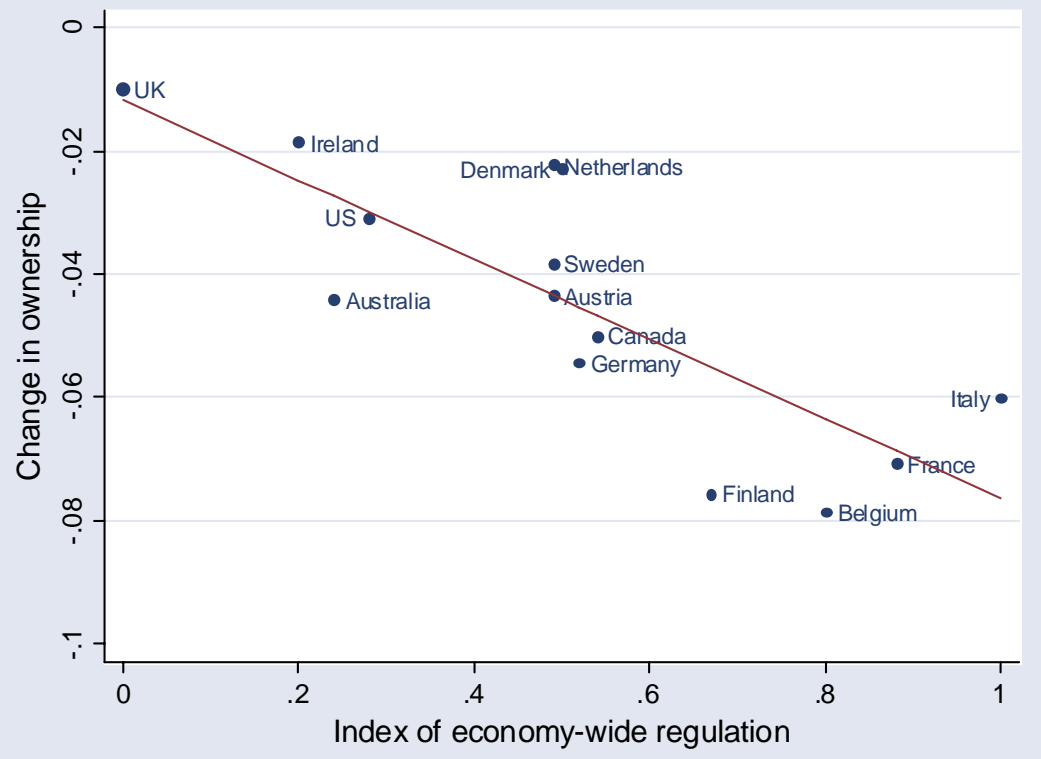

Note. The change in ownership is the cohort-adjusted change in ownership between age 75 and 80 . 
Table 1

The international dataset

\begin{tabular}{|c|c|c|c|}
\hline Country & Surveys and years available & $\begin{array}{c}\text { Number of } \\
\text { individuals per } \\
\text { survey }\end{array}$ & $\begin{array}{l}\text { Average cell } \\
\text { size }\end{array}$ \\
\hline Australia & $\begin{array}{l}\text { Australian Income and Housing Costs Survey: 1981, 1989, } \\
1994\end{array}$ & 14,916 & 262 \\
\hline Austria & $\begin{array}{l}\text { Austrian Micro-census: 1987, } 1995 \\
\text { European Community Household Panel: } 1997\end{array}$ & 16,524 & 178 \\
\hline Belgium & $\begin{array}{l}\text { Survey of the Centre for Social Policy: 1985, 1988, 1992, } \\
\text { 1997; Panel Study of Belgium Households: } 2000\end{array}$ & 8,567 & 55 \\
\hline Canada & $\begin{array}{l}\text { SCF: } 1975,1981,1987,1991,1994,1997 \text {; Survey of } \\
\text { Labour and Income Dynamics: } 2000\end{array}$ & 61,718 & 290 \\
\hline Denmark & Income Tax Survey: 1987, 1992 & 7,530 & 121 \\
\hline Finland & Income Distribution Survey: 1987, 1991, 1995, 2000 & 15,716 & 212 \\
\hline France & Household Budget Survey: 1984, 1989, 1994 & 11,974 & 129 \\
\hline Germany & $\begin{array}{l}\text { German Socio Economic Panel Study: 1984, 1989, 1994, } \\
2000\end{array}$ & 9,724 & 78 \\
\hline Ireland & $\begin{array}{l}\text { ESRI: 1987; European Community Household Panel: 1996, } \\
2000\end{array}$ & 3,864 & 31 \\
\hline Italy & $\begin{array}{l}\text { Bank of Italy Survey of Household Income and Wealth: } \\
\text { 1986, 1991, 1993, 1995, 1998, } 2000\end{array}$ & 23,429 & 126 \\
\hline Luxembourg & $\begin{array}{l}\text { Luxembourg Social Economic Panel Study: 1985, 1997, } \\
2000\end{array}$ & 2,889 & 24 \\
\hline Netherlands & $\begin{array}{l}\text { Enquiry on the Use of Public Services: 1983, 1987. Socio- } \\
\text { Economic Panel: 1991, 1994, } 1999\end{array}$ & 7,427 & 48 \\
\hline Sweden & Income Distribution Survey: 1992, 1995 & 14,650 & 236 \\
\hline United Kingdom & $\begin{array}{l}\text { Family Expenditure Survey: 1991, } 1995 \\
\text { Family Resource Survey: } 1999\end{array}$ & 17,298 & 139 \\
\hline United States & $\begin{array}{l}\text { March Current Population Survey: 1974, 1979, 1986, 1991, } \\
\text { 1994, 1997, } 2000\end{array}$ & 71,899 & 331 \\
\hline All countries & 60 surveys & 300,967 & 157 \\
\hline
\end{tabular}

Note. The number of observations refers to the country average number of women aged 50 to 80 . 
Table 2

Sample composition by age groups

\begin{tabular}{|c|c|c|c|c|c|c|}
\hline \multirow[t]{2}{*}{ Country } & \multicolumn{2}{|c|}{ Age 51-60 } & \multicolumn{2}{|c|}{ Age 61-70 } & \multicolumn{2}{|c|}{ Age 71-80 } \\
\hline & Households & Individuals & Households & Individuals & Households & Individuals \\
\hline Australia & 41.45 & 39.13 & 33.91 & 33.84 & 24.65 & 27.04 \\
\hline Austria & 42.27 & 38.74 & 34.45 & 34.41 & 23.28 & 26.85 \\
\hline Belgium & 45.54 & 44.87 & 34.76 & 34.49 & 19.70 & 20.64 \\
\hline Canada & 43.59 & 41.95 & 30.20 & 29.67 & 26.21 & 28.38 \\
\hline Denmark & 41.62 & 40.07 & 33.76 & 33.16 & 24.62 & 26.77 \\
\hline Finland & 52.84 & 50.99 & 32.23 & 31.90 & 14.93 & 17.11 \\
\hline France & 45.32 & 43.48 & 34.00 & 34.14 & 20.68 & 22.38 \\
\hline Germany & 48.55 & 45.54 & 33.26 & 33.74 & 18.20 & 20.72 \\
\hline Ireland & 45.59 & 44.72 & 32.87 & 32.09 & 21.53 & 23.19 \\
\hline Italy & 46.52 & 44.89 & 33.80 & 33.85 & 19.67 & 21.26 \\
\hline Luxembourg & 47.63 & 45.66 & 31.56 & 30.91 & 20.81 & 23.43 \\
\hline Netherlands & 44.44 & 42.56 & 34.59 & 35.22 & 20.97 & 22.22 \\
\hline Sweden & 47.29 & 45.94 & 28.61 & 27.96 & 24.10 & 26.10 \\
\hline United Kingdom & 41.81 & 40.47 & 33.92 & 33.56 & 24.27 & 25.97 \\
\hline United States & 46.52 & 44.90 & 31.37 & 31.33 & 22.12 & 23.77 \\
\hline
\end{tabular}

Note. The table reports the percentage of household heads and women by each age group. Statistics are computed using sample weights. Country values are aggregated over different years. 
Table 3

Ownership by age group

\begin{tabular}{l|ccc}
\hline Country & Age 51-60 & Age 61-70 & Age 71-80 \\
\hline Australia & 82.16 & 81.02 & 71.76 \\
Austria & 67.04 & 60.69 & 47.16 \\
Belgium & 77.60 & 74.89 & 65.33 \\
Canada & 78.62 & 73.73 & 58.98 \\
Denmark & 65.40 & 54.02 & 43.65 \\
Finland & 83.54 & 75.10 & 61.62 \\
France & 69.27 & 67.56 & 55.11 \\
Germany & 49.62 & 50.62 & 41.44 \\
Ireland & 89.93 & 87.82 & 78.24 \\
Italy & 69.74 & 64.36 & 50.02 \\
Luxemburg & 79.23 & 71.89 & 57.90 \\
Netherlands & 44.92 & 33.41 & 22.67 \\
Sweden & 75.39 & 69.12 & 53.32 \\
United Kingdom & 75.93 & 67.08 & 55.58 \\
United States & 76.52 & 76.92 & 72.03 \\
\hline
\end{tabular}

Note. The table reports the percentage of women owning a home by age group. Country values are averaged over different years. 
Table 4

Index of mortgage market and economy-wide regulation, property taxes, and number of beds in nursing homes: international comparisons

\begin{tabular}{l|cccc}
\hline & $\begin{array}{c}\text { Index of mortgage } \\
\text { market regulation }\end{array}$ & $\begin{array}{c}\text { Index of economy } \\
\text { wide regulation }\end{array}$ & $\begin{array}{c}\text { Property tax to GDP } \\
\text { ratio }\end{array}$ & $\begin{array}{c}\text { Number of beds in } \\
\text { nursing homes }\end{array}$ \\
\hline & & & & \\
Australia & 0.1 & 0.24 & 0.027 & 4.8 \\
Austria & 0.9 & 0.49 & 0.006 & 1.7 \\
Belgium & 0.9 & 0.80 & 0.013 & 2.9 \\
Canada & 0.5 & 0.54 & 0.037 & 12.2 \\
Denmark & 0.3 & 0.50 & 0.017 & 5.1 \\
Finland & 0.5 & 0.67 & 0.011 & 4.3 \\
France & 0.7 & 0.88 & 0.024 & 1.3 \\
Germany & 0.7 & 0.52 & 0.010 & 8.6 \\
Ireland & 0.1 & 0.20 & 0.016 & 6.9 \\
Italy & 0.9 & 1.00 & 0.023 & 2.7 \\
Luxembourg & 0.3 & $n . a$ & 0.036 & 5.9 \\
Netherlands & 0.5 & 0.49 & 0.019 & 3.8 \\
Sweden & 0.3 & 0.49 & 0.020 & 5.4 \\
UK & 0.1 & 0.00 & 0.038 & 3.1 \\
US & 0.3 & 0.28 & 0.032 & 5.4 \\
\hline
\end{tabular}

Note. The index of mortgage market regulation is taken from Tsatsaronis and Zhu (2004). The score adds one point for fulfilling each of the following five criteria: (1) Mortgage rate arrangement are primarily extended on the basis of fixed rate contracts; (2) Mortgage equity withdrawals is absent or limited; (3) The loan-to-value ratio does not exceed 75 percent; (4) Valuation methods of property is based on historical values, rather than based on market values; (5) Mortgage backed securitization is absent or limited. The index is then normalized to one. The index of economy wide regulation is taken from Nicoletti and Scarpetta (2003). The index is a wide indicator of the degree of economic regulation covering many different regulatory areas (state control, barriers to entrepreneurship, administrative regulations, tariff and non-tariff barriers, etc.) aggregated through factor analysis. The property tax to GDP ratio is drawn from OECD (2002). Number of beds in nursing homes per thousand inhabitants refers to 2003 or closest year available and is taken from OECD Health Data (2005) CD -Rom. 
Table 5

Regressions for change in ownership

\begin{tabular}{|c|c|c|c|c|c|c|c|c|c|}
\hline \multirow[b]{2}{*}{ Index of mortgage market regulation } & \multicolumn{3}{|c|}{ From 70 to 75} & \multicolumn{3}{|c|}{ From 75 to 80} & \multicolumn{3}{|c|}{ From 75 to 80, with demographics } \\
\hline & $\begin{array}{l}-0.003 \\
(0.019)\end{array}$ & & $\begin{array}{c}0.007 \\
(0.018)\end{array}$ & $\begin{array}{c}-0.078 \\
(0.034)^{* *}\end{array}$ & & $\begin{array}{l}-0.008 \\
(0.033)\end{array}$ & $\begin{array}{c}-0.070 \\
(0.010) * * *\end{array}$ & & $\begin{array}{l}-0.013 \\
(0.039)\end{array}$ \\
\hline Index of economy-wide regulation & & $\begin{array}{l}-0.029 \\
(0.017)\end{array}$ & $\begin{array}{l}-0.035 \\
(0.022)\end{array}$ & & $\begin{array}{c}-0.086 \\
(0.027)^{* *}\end{array}$ & $\begin{array}{c}-0.079 \\
(0.041)^{*}\end{array}$ & & $\begin{array}{c}-0.082 \\
(0.034)^{* *}\end{array}$ & $\begin{array}{c}-0.071 \\
(0.047)^{*}\end{array}$ \\
\hline Property tax to GDP ratio & $\begin{array}{c}0.436 \\
(0.448)\end{array}$ & $\begin{array}{c}0.185 \\
(0.459)\end{array}$ & $\begin{array}{c}0.210 \\
(0.447)\end{array}$ & $\begin{array}{c}0.394 \\
(0.918)\end{array}$ & $\begin{array}{c}0.776 \\
(0.725)\end{array}$ & $\begin{array}{c}0.680 \\
(0.849)\end{array}$ & $\begin{array}{c}-0.043 \\
(0.272)\end{array}$ & $\begin{array}{c}0.491 \\
(0.919)\end{array}$ & $\begin{array}{c}0.396 \\
(0.978)\end{array}$ \\
\hline Number of beds in nursing homes & $\begin{array}{c}0.038 \\
(0.202)\end{array}$ & $\begin{array}{l}-0.157 \\
(0.116)\end{array}$ & $\begin{array}{l}-0.147 \\
(0.109)\end{array}$ & $\begin{array}{l}-0.002 \\
(0.296)\end{array}$ & $\begin{array}{c}0.017 \\
(0.184)\end{array}$ & $\begin{array}{c}0.012 \\
(0.208)\end{array}$ & $\begin{array}{c}0.118 \\
(0.088)\end{array}$ & $\begin{array}{c}0.055 \\
(0.233)\end{array}$ & $\begin{array}{c}0.048 \\
(0.239)\end{array}$ \\
\hline English legal origin & $\begin{array}{l}-0.001 \\
(0.010)\end{array}$ & $\begin{array}{l}-0.009 \\
(0.013)\end{array}$ & $\begin{array}{l}-0.008 \\
(0.012)\end{array}$ & $\begin{array}{l}-0.016 \\
(0.022)\end{array}$ & $\begin{array}{l}-0.025 \\
(0.021)\end{array}$ & $\begin{array}{l}-0.024 \\
(0.023)\end{array}$ & $\begin{array}{l}-0.008 \\
(0.007)\end{array}$ & $\begin{array}{l}-0.024 \\
(0.026)\end{array}$ & $\begin{array}{l}-0.024 \\
(0.027)\end{array}$ \\
\hline Constant & $\begin{array}{c}-0.038 \\
(0.023)\end{array}$ & $\begin{array}{l}-0.010 \\
(0.012)\end{array}$ & $\begin{array}{l}-0.012 \\
(0.012)\end{array}$ & $\begin{array}{l}-0.006 \\
(0.033)\end{array}$ & $\begin{array}{c}-0.009 \\
(0.019)\end{array}$ & $\begin{array}{c}-0.007 \\
(0.023)\end{array}$ & $\begin{array}{c}-0.013 \\
(0.010)\end{array}$ & $\begin{array}{c}-0.004 \\
(0.024)\end{array}$ & $\begin{array}{c}-0.001 \\
(0.026)\end{array}$ \\
\hline $\begin{array}{l}\text { Observations } \\
\text { R-squared }\end{array}$ & $\begin{array}{c}15 \\
0.19\end{array}$ & $\begin{array}{c}14 \\
0.37\end{array}$ & $\begin{array}{c}14 \\
0.45\end{array}$ & $\begin{array}{c}15 \\
0.43\end{array}$ & $\begin{array}{c}14 \\
0.63\end{array}$ & $\begin{array}{c}14 \\
0.60\end{array}$ & $\begin{array}{c}15 \\
0.88\end{array}$ & $\begin{array}{c}14 \\
0.46\end{array}$ & $\begin{array}{c}14 \\
0.48\end{array}$ \\
\hline
\end{tabular}

Note. The table reports robust regressions for cohort-adjusted changes in ownership from age 70 to 75 , and from age 75 to 80 . The last three columns estimate cohort-adjusted changes in ownership when age profiles estimates control also for education and working status. Standard errors are reported in parentheses. One star denotes significance at the 10 percent level; two stars at the 5\% level; three stars at the at the $1 \%$ level. 


\section{CFS Working Paper Series:}

\begin{tabular}{|c|c|c|}
\hline No. & Author(s) & Title \\
\hline 2008/19 & Annamaria Lusardi & $\begin{array}{l}\text { Financial Literacy: An Essential Tool for Informed } \\
\text { Consumer Choice? }\end{array}$ \\
\hline 2008/18 & Annamaria Lusardi & $\begin{array}{l}\text { Increasing the Effectiveness of Financial Education } \\
\text { in the Workplace }\end{array}$ \\
\hline 2008/17 & Volker Wieland & $\begin{array}{l}\text { Learning, Endogenous Indexation and Disinflation } \\
\text { in the New-Keynesian Model }\end{array}$ \\
\hline $2008 / 16$ & $\begin{array}{l}\text { Athanasios Orphanides } \\
\text { Volker Wieland }\end{array}$ & $\begin{array}{l}\text { Economic Projections and Rules-of-Thumb for } \\
\text { Monetary Policy }\end{array}$ \\
\hline $2008 / 15$ & $\begin{array}{l}\text { Jan Pieter Krahnen } \\
\text { Christian Wilde }\end{array}$ & Risk Transfer with CDOs \\
\hline $2008 / 14$ & $\begin{array}{l}\text { Stefan Mittnik } \\
\text { Tina Yener }\end{array}$ & $\begin{array}{l}\text { Value-at-Risk and Expected Shortfall for Rare } \\
\text { Events }\end{array}$ \\
\hline 2008/13 & $\begin{array}{l}\text { Serena Lamartina } \\
\text { Andrea Zaghini }\end{array}$ & $\begin{array}{l}\text { Increasing Public Expenditures: Wagner's Law in } \\
\text { OECD Countries }\end{array}$ \\
\hline 2008/12 & $\begin{array}{l}\text { Jürgen Gaul } \\
\text { Erik Theissen }\end{array}$ & $\begin{array}{l}\text { A Partially Linear Approach to Modelling the } \\
\text { Dynamics of Spot and Futures Prices }\end{array}$ \\
\hline 2008/11 & $\begin{array}{l}\text { Roman Kräussl } \\
\text { Niels van Elsland }\end{array}$ & $\begin{array}{l}\text { Constructing the True Art Market Index - A Novel } \\
\text { 2-Step Hedonic Approach and its Application to } \\
\text { the German Art Market }\end{array}$ \\
\hline $2008 / 10$ & $\begin{array}{l}\text { Alan Muller } \\
\text { Roman Kräussl }\end{array}$ & $\begin{array}{l}\text { Do Markets Love Misery? Stock Prices and } \\
\text { Corporate Philanthropic Disaster Response }\end{array}$ \\
\hline
\end{tabular}

Copies of working papers can be downloaded at http://www.ifk-cfs.de 